\title{
Genetic Diversity Loss in Chironomus sancticaroli (Diptera: Chironomidae) Exposed to Pyrimethanil Fungicide: an Analysis Using RAPD Technique
}

\author{
Vanessa Colombo-Corbi 1 - Guilherme Rossi Gorni • \\ Thais Sanzovo-Falcoski • Paulo Inácio Costa • \\ Juliano J. Corbi
}

Received: 12 June 2017 / Accepted: 12 September 2017 / Published online: 24 September 2017

(C) Springer International Publishing AG 2017

\begin{abstract}
In the agricultural cultivation, the Pyrimethanil (4,6-dimethyl-N-phenyl-2-pyrimidinamine) fungicide is one of the most widely used compound in monocultures and has been detected in aquatic ecosystems. These genotoxic products increase the frequency of lesions in the DNA molecule, thereby increasing the risk of replication and transcription of altered DNA sequences. This study aimed to assess the loss of genetic diversity of Chironomus sancticaroli, a Brazilian native insect species, exposed to Pyrimethanil fungicide, using RAPDPCR (random amplified polymorphic DNA) technique. The results showed that there was significant loss in the genetic diversity in the organisms exposed to high Pyrimethanil concentrations when compared with control site. Our findings reveal that RAPD-PCR is an effective method to access genetic loss derived to fungicide use and that the agriculture application may lead to a decrease in aquatic biota genetic diversity. This finding has
\end{abstract}

\footnotetext{
V. Colombo-Corbi $(\bowtie) \cdot$ G. R. Gorni

PPG Desenvolvimento Territorial e Meio Ambiente -

Universidade de Araraquara, UNIARA, Araraquara, SP CEP

14801-340, Brazil

e-mail: vanessacolombo25@yahoo.com.br

T. Sanzovo-Falcoski $\cdot$ P. I. Costa

Faculdade de Ciências Farmacêuticas de Araraquara,

Universidade Estadual Paulista "Júlio de Mesquita Filho" -

UNESP, Araraquara, SP 4801-902, Brazil

J. J. Corbi

Departamento de Hidráulica e Saneamento, Escola de Engenharia de São Carlos (EESC), Universidade de São Paulo - USP, C.P. 359, São Carlos, SP 3566-590, Brazil
}

important implications for conservation strategies and ecological management environments.

Keywords Stream · Chironomidae - Agriculture cultivation $\cdot$ Genetic diversity

\section{Introduction}

In the context of agricultural land use, the Pyrimethanil (4,6-dimethyl-N-phenyl-2-pyrimidinamine) is one of the fungicides most widely used in monocultures and has been detected in aquatic ecosystems (Shinn et al. 2015). According to the EFSA (European Food Safety Authority), Pyrimethanil has no potential to bioaccumulate, has a low acute toxicity, is not teratogenic, and seems to have no neurotoxic effect; however, studies have shown toxicity in bioindicator species (Müller et al. 2012; Scherer et al. 2013; Seeland et al. 2013). These studies have used Chironomus riparius species, a common organism used in ecotoxicological tests in other countries. However, in Brazil, this species has been substituted by Chironomus sancticaroli in ecotoxicological tests because of the ease of collecting and cultivating in the laboratory conditions (Strixino and Strixino 1982), and for the reason that this species is native to the country.

After treatment with genotoxic compounds, the change in the RAPD (random amplified polymorphic DNA) profile is clearly identified by the variation of intensity of the bands as well as the gain or loss bands. These differences in the profiles of RAPD reaction of the bands may be related to DNA damage, 
such as structural changes or rearrangements induced by genotoxins (Atienzar et al. 2002). The RAPD technique is very interesting in ecotoxicological analyses because it is simple, sensitive, relatively cheap, and effective for the identification of DNA damage (De Wolf et al. 2004).

\section{Materials and Methods}

Sensitivity tests in C. sancticaroli cultures, which consist of exposing the organisms to different concentrations of a reference substance, were performed. The ring test with the reference substance potassium-chloride $(\mathrm{KCl})$ was carried out according to OECD recommendations (2011). The C. sancticaroli cultures were kept in plastic trays covered with nylon cages to retain the adult organisms. For the acute tests, six larvae of C. sancticaroli were added (IV instar - 7/ $8 \mathrm{~d}$ ) to $240 \mathrm{~mL}$ of test solution with $60 \mathrm{~g}$ of sand sediment in three replicates. The sand sediment was composed of fine sterilized sand. The test lasted $96 \mathrm{~h}$, after which the living organisms were counted. After 10 days, larvae were counted and the organisms were separated and fixed in isopropyl alcohol for the genetic analyses. The following solutions of Pyrimethanil were employed for acute toxicity tests: 25,50 , and $75 \mathrm{mg} . \mathrm{L}^{-1}$ (nominal concentrations) using commercial Mythos ${ }^{\circledR}$ (Bayer S.A.). As the study wanted to cause damage to the genetic material of the larvae, it was purposely used solutions of high concentration of the fungicide.

The larvae were homogenized individually in $500 \mu \mathrm{L}$ CTAB buffer (2\% CTAB, $1.4 \mathrm{~mol} / \mathrm{L} \mathrm{NaCl}, 20 \mathrm{mmol} / \mathrm{L}$ EDTA, $100 \mathrm{mmol} / \mathrm{L}$ Tris- $\mathrm{HCl}$ ) and $16 \mu \mathrm{L}$ proteinase $\mathrm{K}$
$(10 \mathrm{mg} / \mathrm{mL})$ and incubated at $56^{\circ} \mathrm{C}$ for $6 \mathrm{~h}$, then was added the same volume of phenol/chloroform/isoamyl alcohol (25: 24: 1). The DNA was precipitated in $1 \mathrm{~mL}$ of ice cold $100 \%$ ethanol. After incubation for $2 \mathrm{~h}$ at $-20^{\circ} \mathrm{C}$, the DNA was washed with $70 \%$ ethanol. The pellet was resuspended and dissolved in $25 \mu \mathrm{l}$ of TE buffer and stored at $-20{ }^{\circ} \mathrm{C}$.

$>$ Amplification was performed in a volume of $20 \mu \mathrm{l}$ containing buffer (20 mM Tris- $\mathrm{HCl}, \mathrm{pH} 8.4,50 \mathrm{mM}$ $\mathrm{KCl}, 2.5 \mathrm{mM} \mathrm{MgCl}$, dNTP mix at $200 \mathrm{mM}$ each, $50 \mathrm{nM}$ of primers (OPB 4 GGACTGGAGT, OPB 5 TGCGCCCTTC, OPB 6 TGCTCTGCCC, OPB 7 GGTGACGCAG, OPB 17 AGGGAACGAG, OPB 18 CCACAGCAGT), $50 \mathrm{ng}$ of genomic DNA, and $2.5 \mathrm{U}$ of Taq DNA polymerase (Gibco-BRL). Amplification was in a thermal cycler (Perkin Elmer, Norwalk, CT) programmed for $5 \mathrm{~min}$ at $94{ }^{\circ} \mathrm{C}$, followed by 42 cycles of $94{ }^{\circ} \mathrm{C}$ for $1 \mathrm{~min}, 35^{\circ} \mathrm{C}$ for $2 \mathrm{~min}$, and $72{ }^{\circ} \mathrm{C}$ for $2 \mathrm{~min}$. After the final cycle, an additional extension step was performed at $72{ }^{\circ} \mathrm{C}$ for $7 \mathrm{~min}$. PCR products were loaded on a $1.5 \%$ agarose gel at $120 \mathrm{~V}$ in TAE (40 mM Tris acetate, $1 \mathrm{mM}$ EDTA) and quantified after staining with ethidium bromide $(0.5 \mu \mathrm{g} / \mathrm{mL})$ under UV light (Costa et al. 2000).

The difference observed in RAPD profiles (disappearance and appearance of bands in comparison with control RAPD profiles) was scored using a binary matrix by Sequentix - GELQuest 3.2.1 Version. The statistical difference on banding pattern obtained from Pyrimethanil concentrations was tested with ANOVA $(\alpha=0.05)$. In addition, to determine the phenetic diversity in larvae exposed was used the Shannon-Wiener Index $\left(\mathrm{H}^{\prime}\right)$ (De Wolf et al. 2004).
Fig. 1 Pyrimethanil solutions and phenetic diversity (ShannonWiener Index - $\mathrm{H}^{\prime}$ ) of exposed larvae to 25,50 , and $75 \mathrm{mg} . \mathrm{L}^{-1}$ of Pyrimethanil

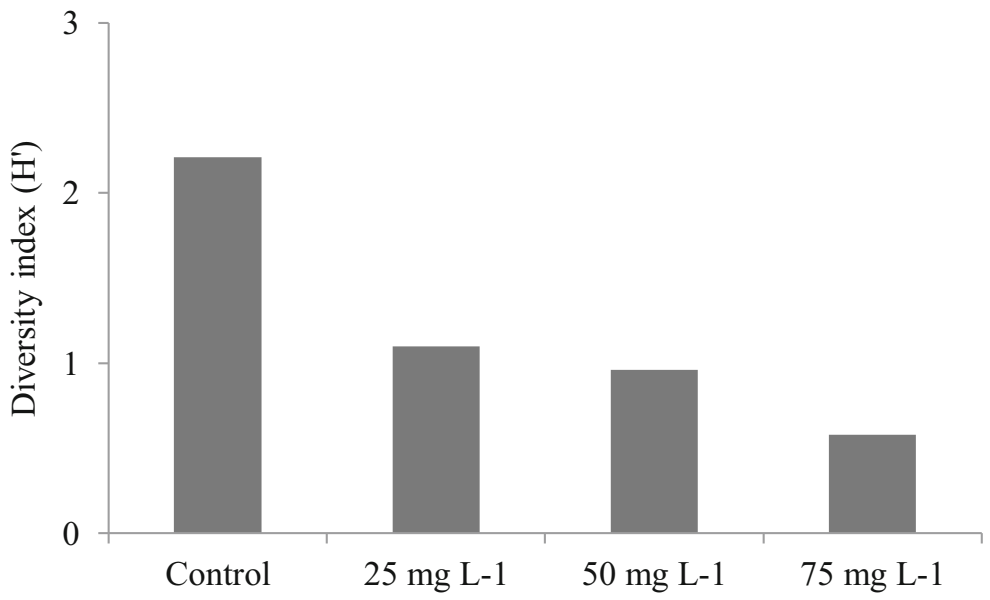




\section{Results}

The genetic diversity was estimated using six primers (OPB4, OPB5, OPB6, OPB7, OPB17, and OPB18) 10 bases. The phenetic diversity was presented in Fig. 1. RAPD profiles revealed substantial differences between the control and exposed organisms. In the organisms without treatment, they were found 58 bands between $2500-250 \mathrm{pb}$. In the organisms treated with fungicides there was a decrease in the number of bands in all tested concentrations. We found 24 bands in the $25 \mathrm{mg} . \mathrm{L}^{-1}$ Pyrimethanil concentration, 21 bands in the $50 \mathrm{mg} . \mathrm{L}^{-1}$ concentration, and 11 bands in the $75 \mathrm{mg} . \mathrm{L}^{-1}$ concentration.

\section{Discussion}

The use of markers to evaluate the genetic variability among individuals and populations is promising because many polymorphic loci can be obtained easily in a relatively short time and at low cost (Nybom 2004). Changes in the pattern of DNA bands may reflect alterations in the genome from a single base variation (point mutations) or chromosomal rearrangements (Atienzar et al. 2002). Considering these data, we can infer that the difference in the profile of the bands obtained in RAPD-PCR reaction of $C$. sancticaroli larvae, exposed to contaminated sediments can refers to toxicity Müller et al. (2012) and Seeland et al. (2013).

\section{Conclusions}

Our findings reveal that RAPD-PCR is an effective method to access genetic loss derived to fungicide use and that Pyrimethanil applications in agriculture cultivation may lead to a decrease in aquatic biota genetic diversity in adjacent areas. This conclusion has decisive consequences for conservation plans and ecological management.
Acknowledgements We thank the São Paulo State Research Aid Foundation (FAPESP) and National Foundation for the Development of Private Higher Education (FUNADESP) for financial support and grants.

\section{References}

Atienzar, F. A., Venier, P., Jha, A. N., \& Depledge, M. H. (2002). Evaluation of the random amplified polymorphic DNA (RAPD) assay for the detection of DNA damage and mutations. Mutation Research, 521(1-2), 151-163.

Costa, P. I., Franco, C. F., Miranda, V. S., Teixeira, D. C., \& Hartung, J. S. (2000). Strains of Xylella fastidiosa rapidly distinguished by arbitrarily primed-PCR. Current Microbiology, 40(4), 279-282.

De Wolf, H., Blust, R., \& Backeljau, T. (2004). The use of RAPD in ecotoxicology. Mutation Research/Genetic Toxicology and Environmental Mutagenesis, 566(3), 249-262.

Müller, R., Seeland, A., Jagodzinski, L. S., Diogo, J. B., Nowak, C., \& Oehlmann, J. (2012). Simulated climate change conditions unveil the toxic potential of the fungicide Pyrimethanil on the midge Chironomus riparius: a multigeneration experiment. Ecological Evolution, 2(1), 196-210.

Nybom, H. (2004). Comparison of different nuclear DNA markers for estimating intraspecific genetic diversity in plants. Molecular Ecology, 13(5), 1143-1155.

OECD - Organization for Economic Cooperation and Development. (2011). 235: Chironomus sp., Acute immobilisation test. $17 \mathrm{p}$.

Scherer, C., Seeland, A., Oehlmann, J., \& Müller, R. (2013). Interactive effects of xenobiotic, abiotic and biotic stressors on Daphnia pulex - results from a multiple stressor experiment with a fractional multifactorial design. Aquatic Toxicology, 138-139(2013), 105-115.

Seeland, A., Albrand, J., Oehlmann, J., \& Müller, R. (2013). Life stage-specific effects of the fungicide pyrimethanil and temperature on the snail Physella acuta (Draparnaud, 1805) disclose the pitfalls for the aquatic risk assessment under global climate change. Environmental Pollution, 174, 1-9.

Shinn, C., Delello-Schneider, D., Mendes, L. B., Sanchez, A. L., Müller, R., Espíndola, E. L. G., \& Araújo, C. V. M. (2015). Immediate and mid-term effects of pyrimethanil toxicity on microalgae by simulating an episodic contamination. Chemosphere, 120, 407-413.

Strixino, S. T., \& Strixino, G. (1982). Ciclo de vida de Chironomus sancticaroli (Diptera: Chironomidae). Revista Brasileira de Entomologia, 26(2), 183-189. 